\title{
Cerebral Palsy and Ayurveda
}

\author{
Avinash $\mathrm{S}^{1 *}$, Amresh $\mathrm{S}^{2}$ and Anuradha Shankar ${ }^{3}$ \\ ${ }^{1}$ Postgraduate in Endocrinology \& Metabolism, National Institute of Health \& Research, \\ India \\ 2Director (Hon) Institute of Applied Neurology, India \\ ${ }^{3}$ Director, Centre for Indigenous Medicine \& Research, India
}

Research Article

Volume 2 Issue 5

Received Date: June 23, 2018

Published Date: July 16, 2018

${ }^{*}$ Corresponding author: Avinash Shankar Postgraduate in Endocrinology \& Metabolism (AIIMS-Delhi) Chairman, National Institute of Health \& Research, Warisaliganj (Nawada) Bihar 805130 India, Tel: 09279380432; Email: dravinashshankar@gmail.com

\section{Abstract}

Cerebral palsy is a commonest chronic and progressive disease of mental and physical disability among children and affects 3-8\% population which fails to respond the present technologies or medication of modern medicine.

Objective of the Study: To evaluate a proven herbal neuro regenerative and neuro vigorative composite NEUROVIT in modifying therapeutic outcome and life style improvement of Cerebral palsy cases.

Material \& Methods: Cases suggestive of Cerebral palsy attending Institute of applied neurology, Aarogyampunarjeevan, Ara Garden Road , Jagdeo path, Baily Road Patna 14 and National Institute of Health \& Research, Warisaliganj (Nawada) Bihar were selected for the study. Selected patients were clinically examined as per various grades of activity to adjudge the severity of illness and investigated for baseline biostatus to evaluate therapeutic outcome and safety profile.

Result: Herbal composite ensured marked improvement in all parameters i.e. motor power, muscle tone, mental capability and intelligent quotient (IQ) in 96.7\% cases without any disease related complication and drug related sequel.

Discussion: Cerebral palsy a chronic condition with considerable morbidity more in male and in lower middle class due to health ignorance unhygienic environment and lack of proper antenatal and obstetric care having increased risk multiple birth, neonatal asphyxia and premature delivery.

Conclusion: Though Cerebral palsy has no cure in modern medicine in spite of advancement in technologies and therapeutics but cases diagnosed at early age and, treated with herbal composite adjuvant NEUROVIT Syrup in prescribed dose with other supplement achieve marked clinical improvement and improved lifestyle in $96.7 \%$ cases.

Keywords: Cerebral Palsy; Spasticity; IQ; Mental Status; Quality of Life 


\section{Journal of Natural \& Ayurvedic Medicine}

\section{Introduction}

Cerebral Palsy (CP) is a commonest chronic motor disorders in children with considerable morbidity and affect about $3-8 \%$ of the population with $15-20 \%$ of physically disabled children and incidence of 3/1000.(WHO ) [1-4]. This affects 2.1 per thousand live births more among poor and male and prevalence average rate is of 2 per thousand most commonly in low birth weight babies. Its incidence increases with premature and low birth weight babies regardless of quality of care. On $\mathrm{n}$ the basis of part affected Cerebral palsy being classified as-Monoplegia, Hemiplegia, Diplegia and quadriplegia out of which diplegia is the commonest (30-40\%), Hemiplegia (20-30\%),quadriplegia (10$15 \%$ ),Spastic quadriplegia $61 \%$ and diplegia $22 \%$ Out of which spastic Cerebral Palsy is the commonest and accounts to $70-75 \%$, dystonic $10-15 \%$ and ataxic $<5 \%$ [58]. Cerebral palsy is not a progressive disorder but manifestations become more prevalent over time and are more likely to have learning disability without affecting IQ including varying degree of intellectual disability with significantly reduced life expectancy depending on severity of condition \& quality of care. 5-10\% of children with Cerebral Palsy die in childhood particularly who had seizure and intellectual disability [9-12]. The ability to ambulate, roll and self feed are the index of increasing life expectancy, in addition independent gross motor functional ability is a very strong determinants of life expectancy [13,14]. The most accurate index of assessment of general movements occurring spontaneous before 4 months age $[15,16]$.

- Abdominal muscle tone

- Delayed motor development

- Persistence of primary reflexes

- Typical symptoms suggestive of diagnosis most commonly occurs at the age of 2 years

Therapeutic outcome in Cerebral Palsy depends on the age of diagnosis, as early the diagnosis better is prognosis. The present study is based on the hypothesis that neural tissue remains same ,as it never grows or multiply after birth and no available modern molecule can regenerate or repair damaged or diseased nerve cells thus a herbal composite of proven efficacy in helping repair and rejuvenation of nerve cells been evaluated in cases of Cerebral palsy.

Ethical Status: Ethical committee of National Institute of Health \& Research approved the extended study to approve the established neurogenic effect of herbal composite

\section{Material \& Methods}

\section{Objective of study}

Evaluation of therapeutic efficacy of a proven herbal neurovigorative and neurogenerative composite in modifying therapeutic outcome and improvement of life style in cases of Cerebral palsy .

\section{Duration of Study}

January 2004 to December 2017, this include follow up period also

\section{Material}

Patients attending at the Institute of Applied Neurology, Aarogyam punarjeevan, Ram Bhawan, Ara Garden Road, Jagdeopath, Baily Road, Patna 14 and National Institute Of Health \& Research Warisaliganj (Nawada) Bihar been considered for the evaluation as per following criteria of selection and exclusion and were diagnosed as per- Children with complaints of spasticity or dysfunction in limbs and delayed developmental milestones and already diagnosed cases of Cerebral Palsy were selected for this study (Table 1).

\begin{tabular}{|c|c|}
\hline Criteriia of selection & Criteria of exclusion \\
\hline $\begin{array}{c}\text { Children with CP up to } 10 \\
\text { years of age }\end{array}$ & Children $>10$ years of age \\
\hline $\begin{array}{c}\text { Children with } \\
\text { developmental delay and } \\
\text { disability with mild, } \\
\text { moderate, or severe degree. }\end{array}$ & $\begin{array}{c}\text { Children with severe } \\
\text { infectious diseases such as } \\
\text { TB, meningitis degree. }\end{array}$ \\
\hline & $\begin{array}{c}\text { Children with any major } \\
\text { congenital } \\
\text { Malformations such as } \\
\text { Congenital } \\
\text { Heart Disease (CHD) }\end{array}$ \\
\hline
\end{tabular}

Table 1: Criteriia of Selection/ Exclusion.

\section{Methods}

Parents of Selected patients were interrogated for antenatal, natal and postnatal history

\section{Birth history}

Hospital /home delivery

Normal/assisted

Delayed labour

LSCS /HSCS

Antenatal drug history

Apgar score 


\section{Journal of Natural \& Ayurvedic Medicine}

Clinical stage (Table 2, 3)

History of any medication
Response of therapy taken

\begin{tabular}{|c|c|}
\hline Motor function & Gradings \\
\hline \multirow[t]{6}{*}{ Head Holding } & $0=$ No head holding \\
\hline & $\mathrm{I}=$ Head erect and steady momentarily \\
\hline & 2=Supine; lifts head when pulled up by arms \\
\hline & $3=$ Prone,elevates self by arms and chest \\
\hline & $4=$ holds head steady when moved around \\
\hline & $5=$ Head balanced always \\
\hline \multirow[t]{6}{*}{ Sitting } & $0=$ Not sitting at all \\
\hline & $1=$ sits momentarily \\
\hline & 2 - Sits for $30 \mathrm{~s}$ or more leaning forward \\
\hline & 3 - Sits with the child's back straight \\
\hline & 4-While sitting, can manipulate a toy \\
\hline & 5 - Raises self to sitting position \\
\hline \multirow[t]{7}{*}{ Standing } & 0 - Does not stand at all \\
\hline & 1 - Stands holding furniture momentarily \\
\hline & 2 - Takes a few steps, both hands hold \\
\hline & 3 - Without support, can stand alone \\
\hline & 4 - Stands up, all by himself by throwing weight on arms \\
\hline & 5 - Takes a few steps without support. \\
\hline & Gross Motor Function Classification system for Cerebral Palsy (GMFCS) Level \\
\hline \multirow[t]{6}{*}{ Fine motor } & 0 - No grasping at all/absent palmer grasp \\
\hline & 1 - Tries to reach and holds thing with crude methods \\
\hline & 2 - Tries to reach and holds things with good grip \\
\hline & 3 - Transfers object from one hand to another hand \\
\hline & 4 - Uses thumb and index finger and holds small object \\
\hline & 5 - Uses end of thumb and index finger/neat pincer grasp \\
\hline \multirow[t]{6}{*}{ Language } & 0 - Unable to speak or produce sound at all \\
\hline & $1-$ Marked cooing \\
\hline & 2- Monosyllable \\
\hline & 3 - Bisyllables \\
\hline & 4 - Two words with meaning \\
\hline & 5 - Makes simple sentence. \\
\hline \multirow[t]{7}{*}{ Personal and social } & 0 - Absent social smile and recognition \\
\hline & 1 - Social smile and recognition \\
\hline & 2 - Recognizing mother \\
\hline & $3-$ Anxiety in front of a stranger \\
\hline & 4-Attachment toward a toy and displeasure on taking it away \\
\hline & 5 - Resists if toy is pulled \\
\hline & 6 - Mimicry, understands spoken words and responds in an appropriate manner \\
\hline
\end{tabular}

Table 2: Patients were assessed for gross motor, gross motor functions and social personal status and were graded as per following assessment scale [16-18]. 


\section{Journal of Natural \& Ayurvedic Medicine}

\begin{tabular}{|c|c|}
\hline Mild & if score of each $>3$ \\
\hline Moderate & if score is 2 \\
\hline Severe & if score is 1 or less \\
\hline
\end{tabular}

Table 3: On the basis of above assessment score patients severity been graded.

Selected patients were given a herbal composite constituting equal part (100mg) of Acorus calamus

Herpestismonnieri, Cassia angustifolia, Nardostacachysjatamansi, Convolvulus pluricaulis in each $5 \mathrm{ml}$ in dose as per following (Tables $4 \& 5$ ):

\begin{tabular}{|c|c|}
\hline$<1 \mathrm{yr}$ & $1.25 \mathrm{ml}$ every $12 \mathrm{hrs}$ \\
\hline $1-5$ years & $2.5 \mathrm{ml}$ every 12 hours \\
\hline $5-10$ years & $5 \mathrm{ml}$ every 12 hours \\
\hline \multicolumn{2}{|c|}{ Along with Calcium, Neuro vitamin and vitamin $\mathrm{D}_{3}$} \\
supplement
\end{tabular}

Table 4: Dose Schedule of Herbal supplements (NEUROVIT Syrup).

\begin{tabular}{|c|c|}
\hline Maximum & $\begin{array}{c}\text { More than 75\% improvement of clinical signs } \\
\text { and symptoms }\end{array}$ \\
\hline Moderate & $\begin{array}{c}\text { More than 50-75\% improvement of clinical } \\
\text { signs and symptoms }\end{array}$ \\
\hline Mild & $\begin{array}{c}\text { More than 25-50\% improvement of clinical } \\
\text { signs and symptoms }\end{array}$ \\
\hline $\begin{array}{c}\text { Non } \\
\text { response }\end{array}$ & $\begin{array}{c}\text { Equal or less than 25\% improvement of } \\
\text { clinical signs and symptoms: }\end{array}$ \\
\hline
\end{tabular}

Table 5: Effect of therapy been assessed and graded.

\section{Observations}

Among 184 selected patients 116 were male and 68 were female, out of all 51 cases were of age $<1$ year while 71 were of $<3$ years though 6 cases were of $>5$ years age (Table 6), (Figure 1). Out of all 96(52.2\%) were delivered normally while $51(27 \%)$ through caesarean section and $100(54.3 \%)$ were with poor Apgar score and 84(41.6\%) with low birth weight (Table 7). Among the selected patients 62 had taken various therapeutic including physiotherapy in last few years without having any improvement while rest 122 have not taken any medication and attended the centre for the first time, though 69 cases were detected during the treatment for other disease (Figure 2). The commonest clinical presentation was speech problem in $82.6 \%$ cases while $52.7 \%$ presents with microcephaly, $44.8 \%$ with seizure and $12 \%$ with behaviour problem (Table 8 ). Birth history reveals majority (64) with low birth weight, 59 premature delivery and 61 with poor Apgar score (not cried after birth). Considering the severity of the presentation 32 were of severe, 60 moderate and 92 with mild grade of presentation (Figure 3). No patients had any drug adversity or agonizing clinical presentation or any alteration in haematological, hepatic and renal function though $98.9 \%$ patient show marked rise in haemoglobin (Table 9). Out of all 178 (96.7\%) children shows grade I (excellent) clinical outcome while $4(2.1 \%)$ and $2(1.1 \%)$ had grade II and grade III improvement (Table 10), (Figure 4).

\begin{tabular}{|c|c|c|c|}
\hline Age group (in year) & \multicolumn{3}{|c|}{ Number of patients } \\
\hline$<1$ year & Male & Female & Total \\
\hline $1-3$ & 34 & 17 & 51 \\
\hline $3-5$ & 42 & 29 & 71 \\
\hline$>5$ & 36 & 20 & 56 \\
\hline & 4 & 2 & 6 \\
\hline & 116 & 68 & 184 \\
\hline
\end{tabular}

Table 6: Distribution of patients as per age and sex.

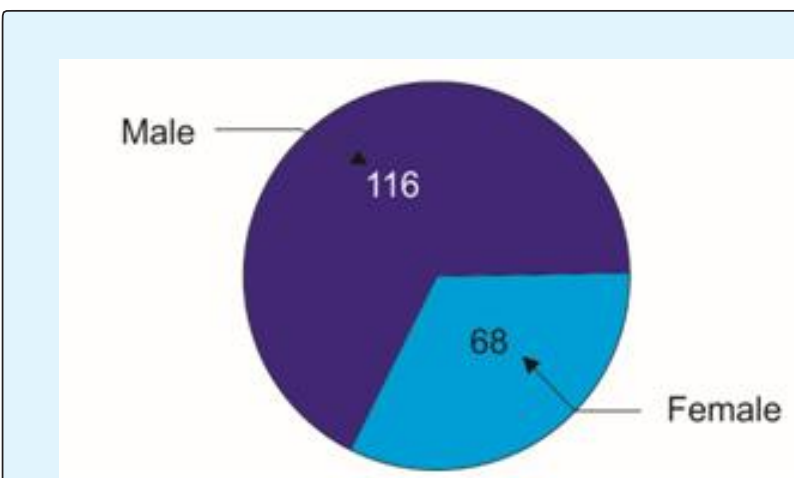

Figure 1: Pie Diagram Showing Sex Wise Composition of Patients.

\begin{tabular}{|c|c|c|}
\hline Particulars & $\begin{array}{c}\text { Number of } \\
\text { patients }\end{array}$ & $\mathbf{\%}$ \\
\hline \multicolumn{2}{|c|}{ Birth history } \\
\hline Normal parturition & 96 & 52.2 \\
\hline Assisted parturition & 37 & 20.1 \\
\hline Forcep & 16 & \\
\hline Episiotomy & 21 & \\
\hline Lower segment caeserian section & 31 & 16.8 \\
\hline Foetal status & 20 & 10.9 \\
\hline Normal & 56 & 30.4 \\
\hline Low birth weight baby & 84 & 45.6 \\
\hline Premature & 44 & 24 \\
\hline Poor apgar score & 100 & 54.3 \\
\hline
\end{tabular}

Table 7: Distribution of patients as per their birth history. 


\section{Journal of Natural \& Ayurvedic Medicine}

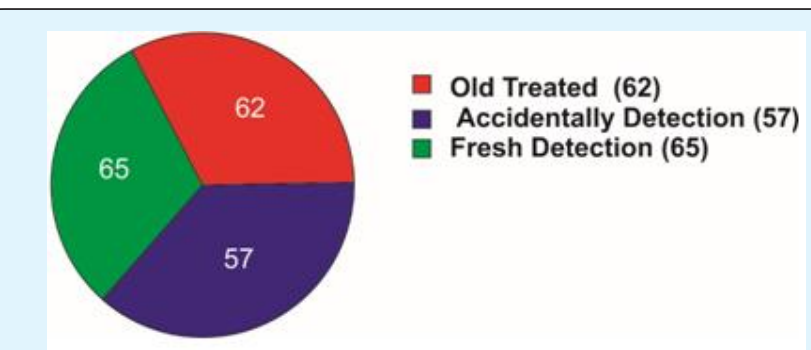

Figure 2: Pie Diagram Distribution of patients as Per their Status.

\begin{tabular}{|c|c|c|}
\hline Presentation & Number & Percentage \\
\hline Speech problems & 152 & 82.6 \\
\hline Microcephaly & 97 & 52.7 \\
\hline Visual defect & 70 & 38.04 \\
\hline Seizures & 75 & 44.8 \\
\hline Malnutrition & 64 & 34.8 \\
\hline Intellectual disability & 62 & 33.7 \\
\hline Feeding problems & 38 & 20.7 \\
\hline Hearing problems & 19 & 10.3 \\
\hline Behavior problems & 22 & 12 \\
\hline
\end{tabular}

Table 8: Distribution of patients as per clinical presentation.

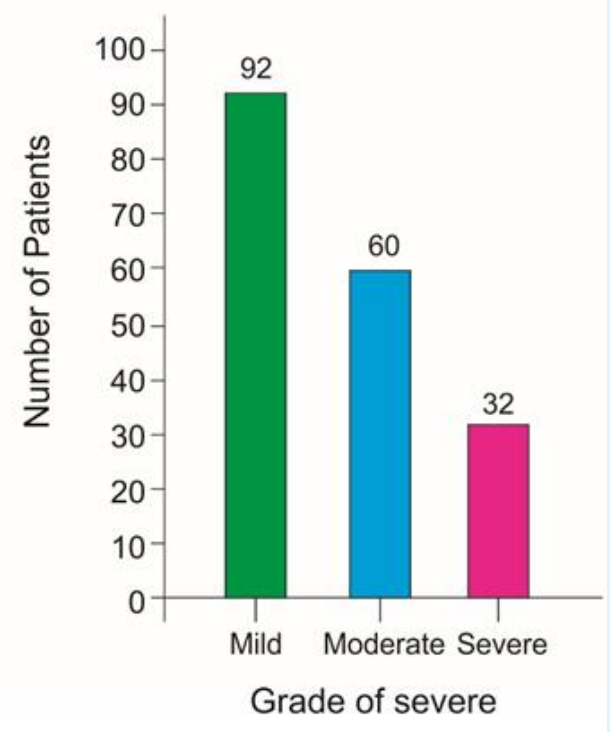

Figure 3: Bar diagram showing distribution of patients as per clinical service.

\begin{tabular}{|c|c|c|}
\hline Bio parameter & \multicolumn{2}{|c|}{ Number of patients } \\
\hline & Before therapy & After therapy \\
\hline \multicolumn{3}{|c|}{ Hematological } \\
\hline \multicolumn{3}{|c|}{ Hemoglobin: } \\
\hline$<12$ gm $\%$ & 134 & 2 \\
\hline$>12 \mathrm{gm} \%$ & 50 & 182 \\
\hline \multicolumn{3}{|c|}{ Hepatic profile } \\
\hline \multicolumn{3}{|c|}{ Serum bilirubin: } \\
\hline$<1 \mathrm{mg} \%$ & 180 & 184 \\
\hline$>1 \mathrm{mg} \%$ & 4 & 0 \\
\hline \multicolumn{3}{|c|}{ SGOT: } \\
\hline$<30 \mathrm{IU}$ & 180 & 184 \\
\hline$>30 \mathrm{IU}$ & 4 & 0 \\
\hline \multicolumn{3}{|l|}{ SGPT } \\
\hline$<30 \mathrm{IU}$ & 180 & 184 \\
\hline$>30 \mathrm{IU}$ & 4 & 0 \\
\hline \multicolumn{3}{|c|}{ Renal profile } \\
\hline \multicolumn{3}{|c|}{ Blood urea: } \\
\hline$<26 \mathrm{mg} \%$ & 182 & 184 \\
\hline$>26 \mathrm{mg} \%$ & 2 & 0 \\
\hline \multicolumn{3}{|c|}{ Serum creatinine: } \\
\hline$<1.5 \mathrm{mg} \%$ & 184 & 184 \\
\hline \multicolumn{3}{|c|}{ Urine: } \\
\hline Albumin & & \\
\hline Present & 2 & 0 \\
\hline Absent & 182 & 184 \\
\hline
\end{tabular}

Table 9: Showing post therapy effect on basic bio parameters.

\begin{tabular}{|c|c|c|c|c|c|c|c|c|c|c|c|c|}
\hline Index & \multicolumn{10}{|c|}{ Number of patients } \\
\hline & \multicolumn{9}{|c|}{ Pre therapy } & \multicolumn{6}{c|}{ Post therapy } \\
\hline Grades & 0 & 1 & 2 & 3 & 4 & 5 & 0 & 1 & 2 & 3 & 4 & 5 \\
\hline Head holding & 32 & 35 & 117 & 0 & 0 & 0 & 0 & 0 & 0 & 2 & 4 & 178 \\
\hline Sitting & 32 & 40 & 112 & 0 & 0 & 0 & 0 & 0 & 0 & 2 & 4 & 178 \\
\hline Standing & 32 & 59 & 93 & 0 & 0 & 0 & 0 & 0 & 0 & 2 & 4 & 178 \\
\hline GMFC level & & & & & & & & & & & & \\
\hline Fine motor & 32 & 40 & 112 & 0 & 0 & 0 & 0 & 0 & 0 & 2 & 4 & 178 \\
\hline Language & 32 & 55 & 97 & 0 & 0 & 0 & 0 & 0 & 0 & 2 & 4 & 178 \\
\hline $\begin{array}{c}\text { Personal \& } \\
\text { Social }\end{array}$ & 32 & 52 & 100 & 0 & 0 & 0 & 0 & 0 & 0 & 2 & 4 & 178 \\
\hline
\end{tabular}

Table 10: Shows therapeutic outcome. 


\section{Journal of Natural \& Ayurvedic Medicine}

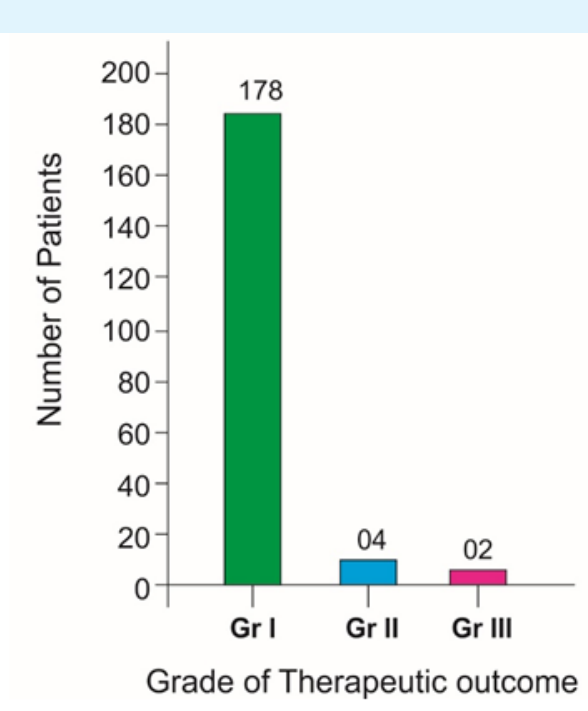

Figure 4: Bar diagram shows therapeutic outcome.

\section{Results}

Herbal composite NEUROVIT ensure marked improvement in motor power, muscular tone and mental capabilities in patients of Cerebral palsy diagnosed and treated at early stage

\section{Discussions}

Cerebral palsy a chronic condition with considerable morbidity more in male and in lower middle class due to health ignorance unhygienic environment and lack of proper antenatal and obstetric care having increased risk multiple birth, neonatal asphyxia and premature delivery. Common symptoms and associated conditions observed in spastic quadriplegia and convulsive disorders [19-21]. As no effective treatment for the underlying brain damage and all sophisticated technology are highly expensive and complicated therapies in the medical research field find a definite cure for the disease. The present study reveals grade I clinical response in majority of early cases and improved quality of life in all the selected cases taking herbal composite NEUROVIT can be explained as Physical and mental debility due to hypoxia, loss of GABA mediated inhibition of dentate granule and death of GABAergic inhibitory neuron results in attenuation of inhibitory control which in turn results in hyper excitation of the remaining neuron of the hippocampus.
Mossy cells (located in dentate hilus, a part of hippocampus) are extremely sensitive to seizure induced neuronal death and damage following intense synaptic activator i.e., excite-tonic mechanism of activator of NMDA (N methyl D aspartate) a sub type of glutamate receptor which results in excessive intracellular calcium. Release of cellular zinc attenuate GABA response and induce hyper -excitability of neurons. GABA binds to GABA-A(coupled to calcium/chloride channel and a main target of currently prescribed drugs) as excitatory post synaptic potential are the main form of communication between neurons and is mediated by release of excitatory amino acid-Glutamate from presynaptic elements which is mediated by - NMDA (N methyl D aspartic acid/aspartate) - AMPA(Alpha-amino-3 hydroxy 5 methyl isoxazole propionic acid) kinate - Metabotropic GABA-B (Couples to potassium channel, a cause of latency and long duration of action) located in pre-synaptic element of an excitatory pre-neuron and inhibits pre-synaptic neuron by - direct induction of IPSP - inhibition of release of excitatory neuro transmitters Hence clinical supremacy of the adjunct indigenous composite can be attributed to bioregulative action of indigenous composites active ingredients for GABA neurodynamics i.e., Nardostachysjatamansi (Jatamansin, Jatamanose, Nardostachine) Herpestismonnieri(Monnerein) bio regulate GABA biokinetics and prompt neurovigorative while Acorus calamus (Acorin, Beta asarone and calaminidine) and Crotolariaverrucosa (crotallidine and verrucosin) acts as a neurogenic and helps in regeneration and repair of damaged neuron due to epileptic attacks thus improve and check neural debility and alleviate physical disability . In addition Convolvulus pluricaulis (Covolvulin) and Herpestismonnieri (Bacoside A \& B) both promote neural growth due to activation of nerve growth factor-Tyrosine kinase A receptor, preserve $m$ RNA level of muscarnic receptors and check accumulation of lipid and protein damage, thus improve both mental ability and capability. Hence bio regulation of altered GABA neuro kinetics prompt neurogenic action improve mental capability and physical capability $[22,23]$. Active ingredients of the composite help revitalization of the damaged or diseased nerve cells improve neuro transmission by bio regulating neuro transmitter secretion ,not only improves physical status i.e.- relieves paresis, improves muscle power, increases muscle bulk and improve deep tendon reflex in addition also improves mental capability and IQ (Figure 5). 


\section{Journal of Natural \& Ayurvedic Medicine}

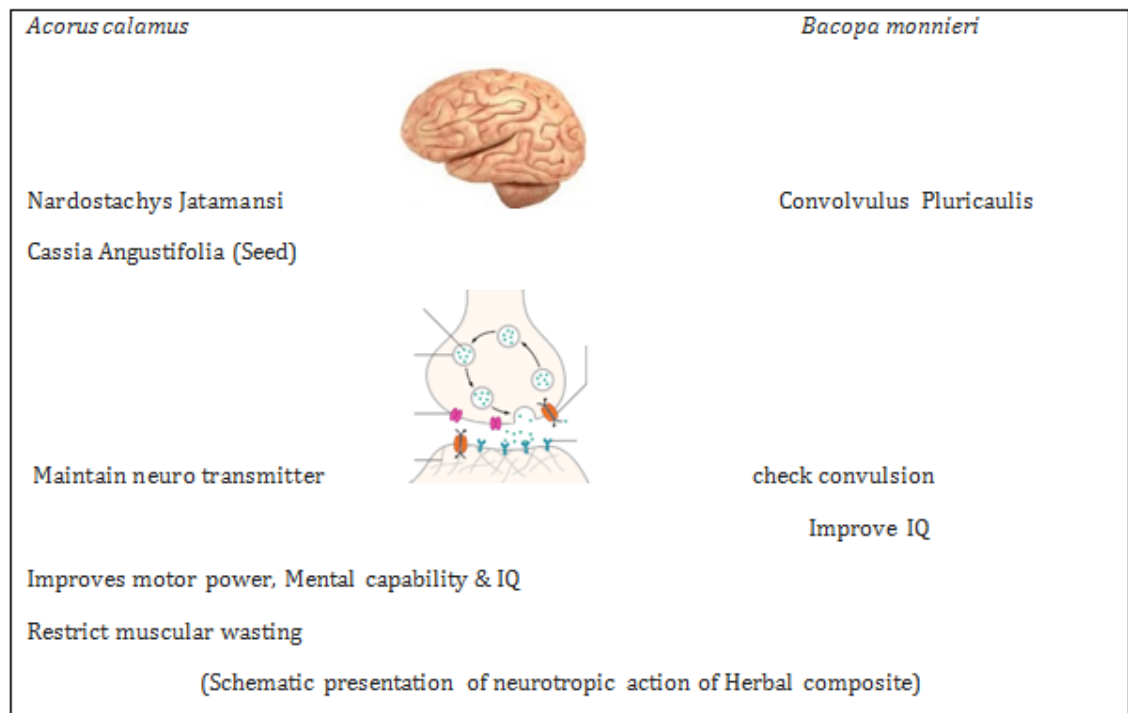

Figure 5: Acorus calamus/ Bacopa monnieri.

Thus NEUROVIT herbal composite seems to be a boon for Cerebral palsy cases in improving quality of life restricting handicap and improving mental capability., earlier the supplement better the outcome.

\section{Conclusion}

Cerebral palsy having no proven therapeutics in modern medicine shows promising result with herbal composite of proven neurogenic and neuro vitalising capacity in cases of cerebral palsy detected at early age i.e. $<2$ years while patients detected late or tried various medication presenting with severe spasticity, have improvement in presentation i.e. muscle power and tone, spasticity and mental ability.

Thus this Herbal composite NEUROVIT is worth prescribing either alone or as an adjuvant in cases of Cerebral palsy as early as possible.

\section{References}

1. Rosenbaum P, Paneth N, Leviton A, Goldstein M, Bax $M$, et al. (2007) A report: the definition and classification of Cerebral Palsy April 2006. Dev Med Child Neurol Suppl 109: 8-14.

2. Jones Kathy (2010) Incidence of Cerebral Palsy Remains Constant in India on Indian Health News.
3. Behrman RE, Kliegman RM, Arvimn AM (1996) Nelson Textbook of Pediatrics. 15 ${ }^{\text {th }}$ (Edn.), Saunders. Philadelphia Cerebral Palsy pp: 1713-1714.

4. Johnson A (2002) Prevalance and Characteristics of Children with Cerebral Palsy in Europe. Dev Med Child Neurol 44(9): 633-640.

5. Laisram N, Srivastava VK, Srivastava RK (1992) Cerebral Palsy-An Etiological Study. Indian J Pediatr 59(6): 723-728.

6. Bottos M, Granato T, Allibrio G, Gioachin C, Puato ML (1999) Prevalence of Cerebral Palsy in North-East Italy from 1965 to 1989. Dev Med Child Neurol 41(1): 26-39.

7. Kavcic A, Perat MW (1998) Prevalence of Cerebral palsy in Slovenia; Birth year 1981-1990. Dev Med Child Neurol 40(7): 459-463.

8. Sharma P, Sharma U, Kabra A (1999) Cerebral Palsy Clinical profile and predisposing factors. Indian Pediatr 36: 1038-1042.

9. Nelson KB, Grether JK (1999) Causes of Cerebral Palsy. Curr Opin Pediatr 11(6): 487-91.

10. Fidan F, Baysal O (2014) Epidemiologic Characteristics of Patients with Cerebral Palsy. Open Journal of Therapy and Rehabilitation 2(3): 126-132. 


\section{Journal of Natural \& Ayurvedic Medicine}

11. Singhi PD, Ray M, Suri G (2002) Clinical Spectrum of Cerebral Palsy in North India-An Analysis of 1000 Cases. J Trop Pediatr 48(3): 162-166.

12. Hoffer MM, Knoebel RT, Roberts R (1987) Contractures in Cerebral Palsy. Clin Orthop Relat Res (219): 70-77.

13. Sundrum R, Logan S, Wallace A, Spencer N (2005) Cerebral palsy and socioeconomic status: A retrospective cohort study. Arch Dis Child 90(1): 1518.

14. Majeed R, Memon Y, Majeed F, Shaikh NP, Rajar UD (2007) Risk factors of birth asphyxia. J Ayub Med Coll Abbottabad 19(3): 67-71.

15. Shoals MG (2007) Cerebral palsy: Diagnosis, Risk factors, Early intervention and Management of the spastic child. In: Datta AK, Sachdeva A, (Eds.), Advances in Pediatrics. 1 ${ }^{\text {st }}$ (Edn.), New Delhi: Jaypee Publishers pp: 623.

16. Johnson A (2002) Prevalence and characteristics of children with cerebral palsy in Europe. Dev Med Child Neurol 44(9): 633-640.

17. Sanger TD, Delgado MR, Deborah D, Hallett M, Mink JW (2003) Task Force on Childhood Motor Disorders
Classification and Definition of Disorders Causing Hypertonia in Childhood. Pediatrics 111(1): e89-e97.

18. Ellison PH (1934) The Infanib A reliable method for the neuromotor assessment of infants. Therapy skill builders, Texas.

19. Menkes JH, Sarnat HB (2000) Periuatal asphyxia and Trauma. Lippincott Williams and Wilkins. Child Neurology pp: 427-436.

20. Palisano RJ, Rosenbaum PL, Walter S, Russell D, Wood E, et al. (1997) Development and reliability of a system to classify gross motor function in child with cerebral palsy. Dev Med Child Neurol 39(4): 214-223.

21. Ellison PH, Horn JL, Browning CA (1985) Construction of an Infant Neurological International Battery (Infanib) for the assessment of neurological integrity in infancy. Phys Ther 65(9): 1326-1331.

22. Shankar A, Shubham (2010) Epidemiological study of epilepsy among children in Jharkhand. The Holistic pediatrics 4: 230-236.

23. Shankar A (2013) Ayurveda for neurological disorder. J Homeop Ayurv Med 2(3): 130-131.

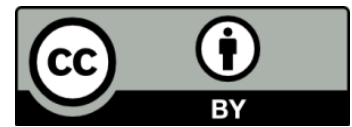

